УДК:347.441:37.015.3:005.32: [001.881:377]

https://doi.org/10.52058/2708-7530-2021-10(16)-378-389

Засць Іван Віталійович молодший науковий співробітник відділу психології праці, Інститут педагогічної освіти і освіти дорослих імені Зязюна НАПН України, м. Київ, вул. Берлінського 9, тел.: (066) 381-39-84, e-mail: vanjuha87@ukr.net, https://orcid.org/0000-0002-6259-5519

\title{
СТРУКТУРНІ СКЛАДОВІ МОТИВАЦІЇ ПРОФЕСІЙНОГО СТАНОВЛЕННЯ ЗДОБУВАЧІВ ПРОФЕСІЙНО-ТЕХНІЧНОЇ ОСВІТИ
}

У статті здійснено теоретичний аналіз проблеми мотивації професійного становлення учнів ПТНЗ; розглянуто актуальність даної тематики; проаналізовано типи мотивації у процесі професійного становлення; розглянуто концепції мотивації професійного становлення особистості; виокремлено структурні складові мотивації професійного становлення; розглянуто особливості мотивації навчальної діяльності; визначено, що мотивація є одним 3 системно утворюючих компонентів професійного становлення особистості; виокремлено професійні мотиви, що відіграють провідну роль у процесі професійного становлення майбутнього фахівця: мотиви професійної діяльності; мотиви професійного спілкування; мотиви прояву особистості в професії; виділено та проаналізовано сім мотиваційних факторів, що впливають на процес професійного становлення особистості: внутрішня мотивація, аксіологічна мотивація, зовнішня мотивація, раціональна мотивація, мотивація, що виникає 3 фрустрації, альтруїстична мотивація, мотивація пов'язана з реалізацією влади; виділено п'ять етапів, які мотив проходить у своєму становленні: виникнення і усвідомлення спонукання, прийняття мотиву, реалізація мотиву, закріплення мотиву, актуалізація спонукання; виокремлено види мотивів, які, на нашу думку, найбільше впливають на мотивацію професійного становлення учнів ПТНЗ: мотив самоствердження, мотив ідентифікації 3 іншою людиною, мотив саморозвитку, мотив досягнення; з'ясовано, що вирішальне значення для досягнення позитивних результатів у рамках навчально-професійної діяльності має саме мотивація досягнення успіху; розроблено структурно-функціональну модель мотивації професійного становлення учнів професійно-технічних закладів.

Ключові слова: мотивація, мотив, професійне становлення, учні ПТНЗ, професійні мотиви, діяльність, внутрішня мотивація, зовнішня мотивація, мотивація досягнення успіху, мотив досягнення. 
Zaiets Ivan Vitaliiovych Junior Research Fellow, Department of Occupational Psychology, Zyazyun Institute of Pedagogical Education and Adult Education, National Academy of Pedagogical Sciences of Ukraine, Berlinskogo St., 9, Kyiv, 04060, tel.: (066) 381-39-84, e-mail: vanjuha87@ ukr.net, https://orcid.org/0000-0002-6259-5519

\title{
THE STRUCTURAL COMPOSITION OF THE MOTIVATION OF PROFESSIONAL DEVELOPMENT OF APPLICANTS FOR VOCATIONAL EDUCATION
}

\begin{abstract}
The article provides a theoretical analysis of the problem of motivation of professional development of vocational school students; the relevance of this topic is considered; the types of motivation in the process of professional development are analyzed; the concepts of motivation of professional development of the personality are considered; the structural components of motivation of professional formation are singled out; features of motivation of educational activity are considered; it is determined that motivation is one of the system-forming components of professional development of personality; the professional motives that play a leading role in the process of professional development of the future specialist are singled out: motives of professional activity; motives of professional communication; motives for the manifestation of personality in the profession; identified and analyzed seven motivational factors that affect the process of professional development of personality: internal motivation, axiological motivation, external motivation, rational motivation, motivation arising from frustration, altruistic motivation, motivation associated with the exercise of power; There are five stages that the motive goes through in its formation: the emergence and awareness of motivation, acceptance of the motive, the realization of the motive, the consolidation of the motive, the actualization of motivation; the types of motives that, in our opinion, have the greatest influence on the motivation of professional development of vocational school students are singled out: the motive of self-affirmation, the motive of identification with another person, the motive of selfdevelopment, the motive of achievement; it was found that the motivation for success is crucial for achieving positive results in the framework of educational and professional activities; a structural-functional model of motivation of professional development of students of vocational schools has been developed.
\end{abstract}

Keywords: motivation, motive, professional development, vocational school students, professional motives, activity, internal motivation, external motivation, motivation to succeed, motive to achieve.

Постановка проблеми. Слід констатувати, що на даний момент дуже мало робіт, які досліджують мотивацію професійного становлення учнів ПТНЗ комплексно, а також досліджень, що розглядають динаміку мотиваційної сфери впродовж всього професійного шляху. Ймовірно, дане питання $є$ надто об'ємним, торкається як різних етапів становлення, так і безлічі супровідних компонентів 
професіоналізації, що ускладнює дослідження.

Слід зазначити, що сукупність мотивів знаходиться між собою в складному нелінійному співвідношенні і це співвідношення може бути різним і на різних стадіях професійного становлення. Це питання постає достатньо актуальним для аналізу професійних мотивів учнів ПТНЗ.

Необхідно сказати, що розглядаємо професійне становлення особистості як одну 3 найскладніших психологічних проблем, рішення якої на сучасному етапі розвитку суспільства має принципове значення для проектування процесу професійного становлення особистості, виявлення резервів іï професійного розвитку. Як засвідчує аналіз наукових досліджень головну роль у цьому процесі займає саме розвиток мотиваційної складової, яка є визначальним конструктом поведінки особистості.

Аналіз останніх досліджень і публікацій. Складність та багатоаспектність проблеми мотивації професійного становлення особистості зумовлює 3'ясування психологічних детермінант, які обумовлюють цей процес. (С. Л. Рубінштейн, В. Г. Асєєв, О. М. Леонтьєв, А. Маслоу, Х. Хекхаузен). Питанням психології праці і мотивації професіоналізму присвячені роботи багатьох вітчизняних учених, таких як О.О. Бодальов, Е.Ф. Зеєр, А.К. Маркова, С.О. Клімов та інших.

На загальнотеоретичному рівні положення про вплив особливостей мотивації навчальної діяльності на ii продуктивність обгрунтовано в роботах Д.Б. Ельконіна, Г.С. Леонтьєва, С.Д. Максименка, С.Л. Рубінштейна. Вивченню онтогенетичного аспекту цієї проблеми присвятили свої наукові розробки Л.І. Божович, I.В. Дубровина, С.С. Занюк тощо.

Професійне становлення здійснюється в результаті комплексної взаємодії різноманітних чинників, де в якості внутрішнього стрижня виступає внутрішня (усвідомлена або не усвідомлена) мотивація, схильності, своєрідний «потяг» людини. Теоретичні передумови розробки цієї проблеми вивчались у психологопедагогічних дослідженнях психічного розвитку особистості таких вчених, як Г.О.Балл, І.Д.Бех, М.Й.Боришевський, І.А.Зязюн, Г.С.Костюк, Н.Г.Ничкало, П.С.Перепелиця, В.В.Рибалка, В.О.Семиченко, О.В.Скрипченко та інших. Проблема мотивації професійного становлення поступово вичленовувалась у розробках таких вітчизняних психологів, як Б.Г.Ананьєв, О.Ю.Голомшток, Ф.М.Гоноболін, Є.О.Клімов, Н.І.Литвинова, В.О.Моляко, В.Ф.Моргун, О.Г.Мороз, Д.Ф.Ніколенко, Н.А.Побірченко, В.В.Синявський, В.О.Сластьонін, М.Л.Смульсон, Б.О.Федоришин тощо.

Мета статті: здійснити аналіз та обгрунтування структурних складових мотивації професійного становлення здобувачів професійно-технічної освіти; виокремити види мотивів, які найбільше впливають на мотивацію професійного становлення учнів ПТНЗ; розробити структурно-функціональну модель мотивації професійного становлення учнів професійно-технічних закладів.

Виклад основного матеріалу. Мотивація є одним із системно утворюючих компонентів професійного становлення особистості. Так, О. О. Бодальов, 
Е.Ф. Зеєр, А.К. Маркова, Є.О. Клімов, Леонтьев А. Н. вважають, що цей компонент виконує ряд функцій (спонукальну, спрямувальну, регулювальну) та визначає спрямованість активності людини в професійній поведінці в цілому та іiі орієнтації на різні сторони як професійної, так і позапрофесійної сфери [3, 39; 4, 509; 6, 87]. Також вищезазначені науковці вважають, що мотивація професійного становлення являє собою складну ієрархічно структуровану систему в яку входять покликання, професійні наміри, потреба в професійній праці, професійна схильність, ціннісні орієнтації, мета, домагання, очікування, смисли, установки, готовність до професійної діяльності, професійні інтереси і потреби, спрямованість, а також задоволеність професійною діяльністю.

Згідно, запропонованої А.А. Файзулаевим послідовної концепції структури мотиваційного процесу виділяють п’ять етапів, які мотив проходить у своєму становленні $[13,89]$ :

1.Виникнення i усвідомлення спонукання. В якості спонукання можуть виступати не тільки прямі активатори (потреби, схильності, потяги), а і будь-яке явище психічної діяльності (образи, думки, емоції). Саме спонукання ще не $\epsilon$ мотивом. Першим кроком до формування мотиву $\epsilon$ свідоме спонукання яке включає в себе усвідомлення як предметного змісту спонукання, так і діяльності 3 ним.

2.Прийняття мотиву. На цьому етапі мотиваційна тенденція знаходить якісно чіткі, окреслені властивості (усвідомленості, направленості) і починає виконувати сенсоутворюючу функцію.

3.Реалізація мотиву. Трансформації, які відбуваються 3 виділеною мотиваційною тенденцією в конкретних життєвих ситуаціях (безпосередньої ситуації, іiі реалізації). Виникають нові функції: задоволення, насищення потреби, інтересу.

4.Закріплення мотиву. Повторення однотипних відповідних ситуацій, стимулювання потреби в житті людини, призводить до закріплення мотиву у якості риси характеру.

5.Актуалізація спонукання. Повтори ситуацій актуалізації i задоволення відповідних потреб призводить до закріплення відповідної мотиваційної тенденції як внутрішньої потреби, звички.

Провідну роль у процесі професійного становлення майбутнього фахівця відіграють, як зауважує А.К. Маркова, професійні мотиви, а саме: мотиви розуміння призначення професії; мотиви професійної діяльності (діяльніснопроцесуальні і діяльнісно-результативні); мотиви професійного спілкування (мотиви престижу професії в суспільстві, соціальної співпраці в професії, міжособистісного спілкування в професіі); мотиви прояву особистості в професії (мотиви розвитку і самореалізації особистості і розвитку індивідуальності в професіi). Різні спонуки, що входять в професійну мотивацію, знаходяться між собою в складному нелінійному співвідношенні. Одна i та ж потреба може 
виражатися в різних мотивах i, навпаки, на основі декількох різних потреб (у праці, в самореалізації) може виникнути один мотив (наприклад, вибору престижної професії). При цьому поєднання різних мотивів може викликати одну ціль, і в той же час, один мотив може ініціювати декілька професійних цілей [7, 243].

У процесі професійного становлення особистості, як засвідчує аналіз наукових джерел, мотивація може мати різний характер. Зокрема, В.Е. Мільман $[10,166]$ розрізняє продуктивний і споживчий типи мотивації. У першому випадку спостерігається посилення активності людини, іiі зацікавлене відношення до діяльності та іiі продукту. В цьому випадку для особистості властивий так званий «прогресивний мотиваційний профіль», який означає перевищення загального рівня розвиваючих мотивів над рівнем мотивів підтримки (збереження діяльності на тому ж рівні), і «стенічний» тип емоційного профілю (тобто схильність до активних, діяльних переживань). Інтереси особистості в цьому випадку, швидше за все, знаходитимуться в гармонії із соціально значущими задачами, індивідуально значущі задачі співпадатимуть з суспільно значущими цілями. У другому випадку, при споживчій мотивації, активність суб'єкта буде, скоріше, спрямована на привласнення індивідуально значущої мети, для нього буде характерний «регресивний мотиваційний профіль» (перевищення мотивів підтримки над розвиваючими мотивами) і «астенічний» тип емоційного профілю, який припускає пасивність, агресивність, схильність до захисних реакцій; домінантний (орієнтація на зміст професійної діяльності, творчість в ній, вибіркову активність на справу, стабільно високий рівень домагань); ситуативний (залежність діяльності від обставин, орієнтація на зовнішні чинники, такі як заробіток або місце проживання, виконавську діяльність); конформістський характер (залежність від оточення, емоційна нестійкість, відчуття дискомфорту). При цьому на думку К.О. Абульханової-Славської, конкретна мотивація будується не у відповідності до тих чи інших потреб особистості або вимог ситуацій, а за характерним для неї способом життя [1, 335]. Спосіб життя відповідає типу особистості, iі індивідуальності і визначає загальну стратегію життєвого шляху. В цілому, К.О. Абульханова-Славська поділяє типи життєвих стратегій на основі ініціативи і відповідальності, а також розглядає життєвий шлях людини як здатність організувати свою долю за власним задумом. Відповідно, проблема мотивації, особливо в професійному просторі, може бути розглянута через аналіз життєвих стратегій фахівця.

Згідно концепції Є.П. Варламової, яка виділила типи життєвих ситуацій за відношенням до індивідуальної своєрідності і творчої активності особистості у процесі діяльності, можна виокремити: творчу унікальність, яка відображає творче відношення людини до власного життя, коли іiі перетворююча ініціатива призводить до високої неповторності і екстраординарності подій іiі життя; пасивну індивідуальність, що уявляє собою стихійний, випадковий характер, коли індивідуальна своєрідність людини залежить в основному не від іï зусиль, а 
визначається зовнішніми обставинами; активну типовість, що відображає прагнення людини «бути як всі», коли зусилля спрямовані на досягнення загальноприйнятих цілей i цінностей; пасивну типовість, що характеризує стихійне наслідування людиною соціальних стереотипів, iii сліпе підпорядкування суспільним нормам.

Як вважає Ю.А. Агарков, мотивацію професійного становлення особистості доцільно розглядати як сукупність всіх спонук, які детермінують і регулюють процес професійного і особистісного розвитку. На різних стадіях професійного становлення відбуваються певні зміни в мотиваційній структурі особистості, змінюється «вага» окремих ㄲi компонентів. Кожній стадії відповідає своя мотиваційна структура. Проте, на думку автора, на всіх етапах становлення простежується взаємозв'язок загальних мотиваційних тенденцій. Більш того, необхідно відзначити, що дослідження мотивів і етапів професійного становлення представлене багатьма вченими «в загальному» контексті, як деяка матриця, основа, тоді як кожна професійна сфера володіє власними відмінними рисами.

На основі поєднання існуючих теоретичних концепцій мотивації людини Г. Хім'як виділила сім типів мотиваційних факторів, що впливають на процес професійного становлення особистості: 1) внутрішня мотивація: досягнення, самоактуалізація, почуття власної цінності, задоволеність життям; 2) аксіологічна мотивація: відповідальність, місія, служіння народу; 3) зовнішня мотивація: приязнь, товариський характер, суспільний аспект поведінки; 4) раціональна мотивація: набуття знань і вмінь, новий досвід, вигода; 5) мотивація, що виникає з фрустрації: почуття провини, розв’язання особистих проблем; 6) альтруїстична мотивація: співчуття, альтруїзм, бажання допомогти іншим; 7) мотивація пов’язана з реалізацією влади: досягнення або утримання соціального статусу, кар'єра, престиж, репутація.

В основу побудови навчально-професійної діяльності ставиться завдання сформувати систему мотивів на базі потреб учня в самовираженні, в спілкуванні, в самореалізації. Мова йде про формування особистої відповідальності як виявлення суспільної суті людини, в цілому, і як усвідомлення необхідності практичної реалізації свого перспективного професійного плану.

Розглянемо види мотивів, які, на нашу думку, найбільше впливають на мотивацію професійного становлення учнів ПТНЗ.

Мотив самоствердження. Мотив самоствердження (прагнення утвердити себе в соціумі, в навчальній та професійній діяльності). Він пов'язаний 3 почуттям гідності, честолюбством, самолюбством. Слід зазначити, що самоствердження - це закономірно виникаючий процес, що виявляється в особистості учня і спрямований на виділення та реалізацію своєї «самостійності» (унікальності) в системі соціальних зв'язків. Учень намагається довести навколишнім, що він чогось вартий, прагне здобути певний статус у суспільстві, хоче, щоб його поважали та цінували. Мотив самоствердження $є$ досить дієвим спонукальним фактором, який педагоги намагаються актуалізувати у своїх учнів, 
посилюючи в них мотивацію до навчально-професійної діяльності. Створення спеціальних умов позитивного самоствердження учнів ПТНЗ $є$ одним 3 актуальних завдань, щодо їх навчання та виховання.

Рівень самоствердження учня визначається рівнем його активності у навчально-професійній діяльності. Тому саме мотивація, як джерело активності, виступає невід'ємною частиною самоствердження особистості. Враховуючи все вищесказане слід сказати, що суть поняття «самоствердження» виражає специфічну діяльність виявлення певних якостей, особливостей і характеристик особистості та їх підтвердження в самому собі та оточуючому соціумі. Так, дослідження мотиву самоствердження (С.Л.Братченко, І.С.Кон, М.Р.Міронов, Е.П.Нікітін, Н.Е.Харламенкова) дало змогу вченим виділити його механізми, а саме: саморозкриття, самосприйняття, самовираження, саморегуляція, самопрогнозування.

Мотив самоствердження часто визначає психологічну залежність учня від однолітків. Взагалі, сутність його самоствердження пов'язана 3 відчуттям своєї «самостійності» і «відокремленості» від інших; 3 прагненням до професійного самовизначення; показати себе, стати предметом уваги інших; відстояти особистісну гідність; досягнути переваг; мати владу над собою та іншими; набути впевненості у собі. На процес самоствердження учня ПТНЗ дуже сильно впливає його самооцінка. Особливості самооцінки впливають на всі сторони життя учня: на емоційне самопочуття i взаємини 3 оточуючими, на розвиток творчих здібностей i на успіхи в навчально-професійній діяльності. При низькій самооцінці він недооцінює свої можливості і прагне виконувати тільки прості завдання, що заважає його самоствердженню. При завищеній самооцінці учень ПТНЗ може переоцінювати свої можливості і братися за ті справи, які не в змозі виконати, що також стає не дуже сприятливим засобом самоствердження.

Таким чином, прагнення до самоствердження, до підвищення свого формального і неформального статусу, до позитивної оцінки своєї особистості істотний мотиваційний фактор, який спонукає учня ПТНЗ інтенсивно навчатися працювати і розвиватися.

Мотив ідентифікації з іншою людиною. Цей мотив полягає у прагненні бути схожим на героя, кумира, авторитетну особистість (батька, вчителя тощо). Він $є$ особливо актуальним для молоді, яка намагається наслідувати інших людей у своїй навчально-професійній діяльності. Ідентифікація 3 певною людиною (прагнення бути схожим на неї) приводить до підвищення енергетичного потенціалу індивіда за рахунок символічного «запозичення» енергії в кумира: 3'являються сили, натхнення, бажання працювати, діяти так, як робив це герой, кумир, батько, матір тощо.

Мотив саморозвитку. Прагнення до саморозвитку - це важливий мотив, який спонукає учня багато працювати i розвиватись. На думку А. Маслоу, це прагнення цілковитої реалізації своїх здібностей, впевненість у собі, здатність відчувати свою компетентність. Актуалізація мотиву саморозвитку підсилює в 
особистості іiі мотивацію до навчально-професійної діяльності. Необхідною умовою самореалізації $\epsilon$ саморозвиток. Адже щоб особистість успішно реалізувалась, їй потрібно володіти системою морально-духовних цінностей, які $\epsilon$ змістовою основою цього духовно-практичного процесу [9, 165].

Мотив досягнення. Мотив досягнення - це прагнення досягти високих результатів і майстерності у навчально-професійній діяльності учнів ПТНЗ. Мотивація досягнення проявляється у виборі складних досягнень і намаганні їх виконати. Успіхи в навчально-професійній діяльності залежать не лише від здібностей, навичок, знань, а й від мотивації досягнення, тобто від прагнення досягти високих результатів у цій діяльності. Особистість 3 високим рівнем мотивації досягнення схильна докладати максимальних зусиль у роботі.

Саме в сформованості системи професійно значущих мотивів проявляється професійна зрілість. Спираючись на дослідження Л.П. Овсянецької [12, 209], можна виокремити те, що невизначена i несформована система мотивів абітурієнта під час його вступу до ВН3 (а ми відносимо це і до ПТНЗ) може породжувати пізніше негативні тенденції, які виражаються у розчаруванні вибором, глибокою фрустрацією та нереалізованою уявою щодо освіти, і це, відповідно, веде до невпевненості і внутрішньо особистісного конфлікту (хоча не можна виключати і можливість пристосування до професіï).

Слід зазначити, що Генрі Мюррей, один 3 основоположників напряму досліджень мотивації досягнення, визначав потребу в досягненні як бажання або тенденцію «долати перешкоди, проявляти силу, прагнути робити щось важке або робити щось як можна швидше» $[11,68]$. Він вважав, що привабливість досягнення не в здобутті бажаного, а в розвитку і застосуванні навичок. Іншими словами, мотивацією до досягнення служить сам процес.

Дослідник, Мак-Клелланд стверджує, що мотив досягнення - це похідна від базового спонукання «робити щось краще», причому не для схвалення або нагороди, а «заради самого процесу» [8, 672].

Вирішальне значення для досягнення позитивних результатів у рамках навчально-професійної діяльності має саме мотивація досягнення успіху, яка входить до складу психологічної готовності учня до цієї діяльності. Знання закономірностей розвитку, формування i динаміки мотивації досягнення дозволить успішно вирішити завдання навчання і виховання учнів, їх підготовки до продуктивної, творчої праці.

Як зазначив С. Занюк «мотивація досягнення - це прагнення людини досягти значних результатів, успіхів у діяльності» $[2,302]$. Ми під мотивацією досягнення успіху будемо розуміти прагнення учнів виконувати справу добре, якісно, покращувати результати своєї навчально-професійної діяльності. У психології виділяють чотири чинники, які визначають рівень мотивації досягнення успіху: 1) прагнення до успіху; 2) надія на успіх; 3) суб’єктивно оцінена ймовірність досягнення успіху; 4) суб'єктивні еталони оцінки досягнень.

Як вважає вчений Х. Хекхаузен мотивація досягнення-це збільшити або 
зберегти найвищі здібності людини до всіх видів діяльності, які можна буде застосувати як критерії успішності щодо виконання діяльності і може, привести або до успіху, або до невдачі. Х. Хекхаузен $є$ автором когнітивної моделі мотивації досягнення: «очікування - цінність». Відповідно основними перемінними стають очікування, як суб'єктивна ймовірність, i спонукальна цінність. Мотив сприймається як цілісна, узагальнена диспозиція; а мотивація виникає при взаємодії мотиву i релевантних аспектів ситуації. Отже мотиваційний процес досліджується як взаємодія особистісних диспозицій (мотивів) і особливості ситуації. У цьому мотив досягнення постає як риса чи властивість особистості, що забезпечує стійкість діяльності досягнення стосовно зовнішнім (ситуаційним) впливам. [14, 208].

Зауважимо, що суб'єкти, мотивовані на досягнення успіху, ставлять собі реальну позитивну мету, досягнення якої буде однозначно розцінено як успіх. Такі люди схильні до «розумного» ризику: вибирають завдання середньої складності, де успіх і невдача стають можливими, а результат максимально залежить від власних зусиль. Привабливість завдання зростає пропорційно його складності. Легкі завдання принципово не вибираються, бо приносять задоволення і справжній успіх, а під час виборів занадто важких $є$ велика ймовірність неуспіху.

Проаналізувавши теоретичні уявлення про функції та структуру мотивації особистості та грунтуючись на положеннях концепції професійного становлення Т.В. Кудрявцева [5, 51-60], ми розробили структурно-функціональну модель мотивації професійного становлення учнів професійно-технічних закладів як складного психічного утворення, що виникає i розвивається у процесі формування професійних намірів, професійного навчання, професійної адаптації, реалізації особистості в праці за фахом. На етапі формування професійних намірів провідну функцію виконують мотиви професійного вибору, серед яких: 1) прагнення особистості обрати професію у відповідній сфері діяльності i отримати згідно з обраною спеціальністю необхідну освіту; 2) свідоме позитивне ставлення особистості до обраної сфери професійної діяльності. На етапі професійного навчання провідними стають мотиви навчальної діяльності, серед яких нами виокремлено соціальний та пізнавальний. На етапі професійної адаптації домінуючу функцію виконують мотиви професійної діяльності, серед яких ми зазначили мотиви досягнення успіху та уникнення невдач. I, на етапі професійної реалізації провідну функцію виконують мотиви особистіснопрофесійного саморозвитку, до яких нами віднесено самоактуалізацію та професійні цінності. 


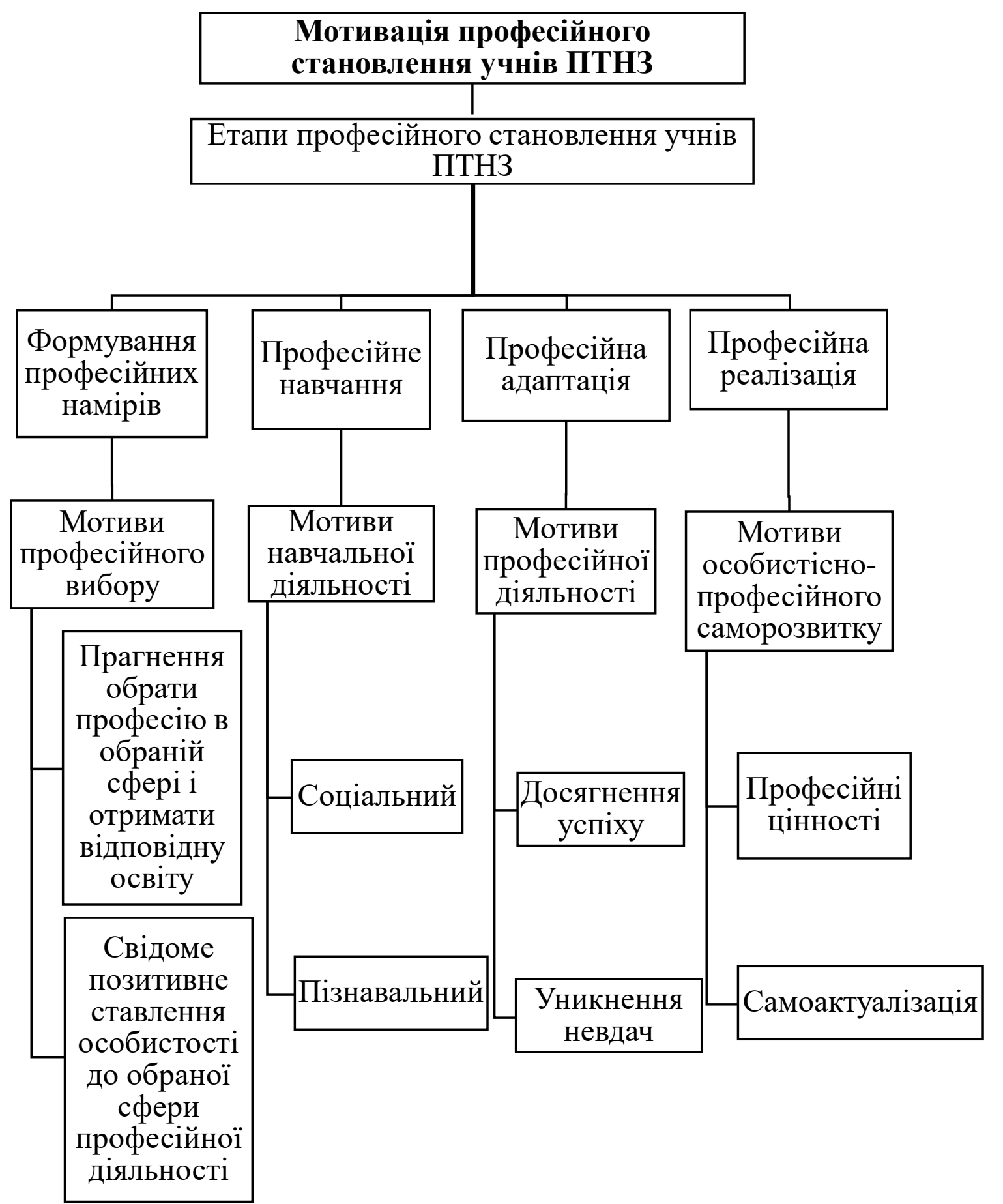

Pис.1. Структурно-функціональна модель мотивачї професійного становлення учнів професійно-технічних навчальних закладів.

Висновки. Отже, мотивація професійного становлення особистості являє собою складне системне утворення яке включає в себе такі властивості особистості як спрямованість, ціннісні орієнтації, потреби, цілі а також різні види мотивів. Саме ці складові мотивують поведінку особистості у процесі іiі професійного становлення. У цілому процес мотивації професійного становлення 
особистості учнів ПТНЗ ми розглядаємо відповідно до особливостей їх мотиваційної сфери, професійного, особистісного розвитку, зрілості майбутнього фахівця, професійного самовизначення та професійної самореалізації.

Нами була розроблена структурно-функціональна модель мотивації професійного становлення учнів професійно-технічних закладів як складного психічного утворення, що виникає i розвивається у процесі формування професійних намірів, професійного навчання, професійної адаптації, реалізації особистості в праці за фахом. На етапі формування професійних намірів провідну функцію виконують мотиви професійного вибору, серед яких: 1) прагнення особистості обрати професію у відповідній сфері діяльності і отримати згідно 3 обраною спеціальністю необхідну освіту; 2) свідоме позитивне ставлення особистості до обраної сфери професійної діяльності. На етапі професійного навчання провідними стають мотиви навчальної діяльності, серед яких нами виокремлено соціальний та пізнавальний. На етапі професійної адаптації домінуючу функцію виконують мотиви професійної діяльності, серед яких ми зазначили мотиви досягнення успіху та уникнення невдач. На етапі професійної реалізації провідну функцію виконують мотиви особистісно-професійного саморозвитку, до яких нами віднесено самоактуалізацію та професійні цінності.

Перспективи подальших пошуків у напрямі дослідження: перспективою розвитку теми мотивації професійного становлення учнів ПТНЗ ми бачимо у проведенні емпіричного дослідження даної тематики та розроблення навчальнорозвивальної програми психолого-педагогічного супроводу мотивації професійного становлення учнів ПТНЗ.

\section{Лimepamypa:}

1. Альбуханова-Славская К. А. (1980). Деятельность и психология личности. - Москва: Наука. -335 с.

2. Занюк С. С. (2002). Психологія мотивачії. - Київ: Либідь. - 302, [1] с.

3. Зеер Э.Ф. (2007). Психология профессионального самоопределения в ранней юности. - Москва: МПСИ; Воронеж НПО МОДЭК. - 39 с.

4. Климов Е. А. (1996). Психология профессионального самоопределения. - Ростов-н/Д.: Феникс. -509 с.

5. Кудрявцев Т. В. (1983). Психологический анализ динамики профессионального самоопределения личности. - Москва: Вопросы психологии. - 51-60 с. [2].

6. Леонтьев А. Н. (1977). Деятельность. Сознание. Личность. - Москва: Политиздат. - 87 с.

7. Маркова А. К. (1993). Психология труда учителя. - Москва: Педагогика. - 243 с.

8. Макклелланд Д. (2007). Мотивация человека. - СПб: Мастера психологии. - 672 с.

9. Маслоу А. (1999). Мотивация и личность. - Санкт-Петербург: Питер. - 165 с.

10. Мильман В.Э. (2005). Мотивация творчества и роста: Структура. Диагностика. Развитие. - Москва: Мирея и ко. - 166 с.

11. Мюррей Г. (1938). Исследование личности. - Нью-Йорк: Оксфорд Університет. - 68 с.

12. Овсянецька Л. П. (1995). Соціально-психологічне прогнозування професійного ставлення майбутнього спеціаліста: [дис. канд. психол. наук]: - Івано-Франківськ. - 209 с.

13. Файзуллаев А. (1987). Мотивационная саморегуляция личности. -Ташкент: Фан. - 89 с. 14.Хекхаузен Х. (1986). Мотивация и деятельность. - Москва: Педагогика. - 208 с. [1 т.]. 


\section{References:}

1. Al'bukhanova-Slavskaya K. A. (1980). Deyatel'nost' i psikhologiya lichnosti [Activity and psychology of personality] - Moskva: Nauka. -335 s. [in Russian].

2. Zanyuk S. S. (2002). Psikhologiya motivatsii [Psychology of motivation] - Kiyev: Lybid'. 302s. [1]. [in Ukraine].

3. Zeyer E.F. (2007). Psikhologiya professional'nogo samoopredeleniya $v$ ranney yunosti [Psychology of professional self-determination in early adolescence] - Moskva: MPSI; Voronezh NPO MODEK. - 39 s. [in Russian].

4. Klimov Ye. A. (1996). Psikhologiya professional'nogo samoopredeleniya [Psychology of professional self-determination]. - Rostov-n / D: Feniks. - 509 s. [in Russian].

5. Kudryavtsev T. V. (1983). Psikhologicheskiy analiz dinamiki professional'nogo samoopredeleniya lichnosti [Psychological analysis of the dynamics of professional selfdetermination]. - Moskva: Voprosy psikhologii. - 51-60 s, [2] [in Russian].

6. Leontev A. N. (1977). Deyatelnost. Soznanie. Lichnost [Activity. Consciousness. Personality]. - Moskva: Politizdat. [in Russian].

7. Markova A. K. (1993). Psikhologiya truda uchitelya [Psychology of teacher work]. Moskva: Pedagogika. - 243 s. [in Russian].

8. MakKlelland D. (2007). Motivatsiya cheloveka [Human motivation]. - SPb: Mastera psikhologii. -672 s. [in Russian].

9. Maslou A. (1999). Motivatsiya i lichnost [Motivation and personality]. - Sankt-Peterburg: Piter. - 165 s. [in Russian].

10. Mil'man V.E. (2005). Motivatsiya tvorchestva i rosta Struktura. Diagnostika. Razvitiye [Motivation for creativity and growth: Structure. Diagnosis. Development]. - Moskva: mire i ko. 166 s. [in Russian].

11. Myurrey G. (1938). Issledovaniye lichnosti [Personality research]. - N'yu-York: Oksford Universitet. [in USA].

12. Ovsyanets'ka L. P. Sotsial'no-psykholohichne prohnozuvannya profesiynoho Stavlennya maybutn'oho spetsialista [Social and psychological prognosis of the professional patronage of the maybutny specialist]: [dys. kand. psykhol. nauk]: - Ivano-Frankivs'k., 1995. - 209 s. [in Ukraine].

13. Fayzullaev A. (1987). Motyvatsiyna samorehulyatsiya osobystosti [Motivational selfregulation of personality]. - Tashkent: Fan. [in Uzbekistan].

14. Hekhauzen H. (1986). Motivatsiya i deyatelnost [Motivation and activity] - Moskva: Pedagogika. [1 t.] [in Russian]. 